\title{
Using Drama Approach and Oral Corrective Feedback in Enhancing Language Intelligibility and Oral Fluency among English Majors
}

\author{
Samah Ahmed Mohammed Elborolosy \\ English Department, Faculty of Science \& Humanities, Shaqraa University, Kingdom of Saudi Arabia
}

\begin{abstract}
The present paper investigated the effect of drama approach and oral corrective feedback on improving English majors intelligibility and oral fluency at Shaqra' University, Kingdom of Saudi Arabia. The tools of the present paper were an interview, pre-posttests, a rubric of the scoring scale and an observation checklist. The participants of the paper were thirty English majors. The paper compared the conventional method to the intervention based on two types of drama approach strategies and three types of oral corrective feedback. Data were statistically analyzed to test the hypotheses. The results indicated that there were no significant differences between the paper groups due to the conventional method in the pretest, whereas there were significant differences in the posttest in favor of the experimental group due to the intervention. Findings of the observation techniques indicated that thought tracking was preferred by the students to soundscape and clarification request mostly used by the teacher.
\end{abstract}

Index Terms—drama approach, oral corrective feedback, oral fluency, intelligibility

\section{INTRODUCTION}

Teachers seek to motivate, direct, and support their students through varying and using creative strategies. Drama approach is one of the most effective, powerful and significant strategies in language teaching and learning, it helps the students to engage in a creative learning and develop their cognitive abilities. Hence, dramatic approach not only helps the students to give different responses during discussing and practicing language skills, but also lead them to accommodate to higher, multiple and more advanced levels of linguistic abilities.

Language oral fluency and speech intelligibility are challenging processes that require great efforts from both teachers and students. Speech intelligibility has a great impact on how the student is able to express a meaningful communication and also affects the way of speaking that reflecting on oral fluency of EFL learners. Intelligibility is the tool that measures the degree of how the speech is understood, so that it is affected by the clarity and comprehensibility of utterance. Intelligibility is a complex cognitive skill, it includes voice quality, speech rate, sentence rhythm and word stress. EFL learners have poorer oral English expression skills, fluency and clarity than English native speakers. To help EFL learners to use accurate forms of the spoken language in meaningful situations, teachers have to focus and develop the factors of intelligibility. Students should have the opportunity to express themselves effectively through reflecting actions and using models for learning and teaching basic oral skills during practice activities in natural communication, hence drama approach could be attributed to achieving a meaningful communication.

(Becker2013; Francis 2014; Weinberger 2013) pointed out the effective role of clarity in improving spoken language. They asserted that intelligibility was an appropriate goal for teaching oral skills and it couldn't be measured accurately. There are few studies that examined the interrelationship between language intelligibility and oral fluency, Thomson (2015) showed there were not enough studies had methodically explored how intelligibility and oral fluency of L2 of the spoken language were interrelated. Blake \& et al (2019) asserted that improving intelligibility enhanced learners of English language and suggested further studies to test the role of intelligibility in determining the effectiveness of different interventions for the speakers of English language. Mallen \& Pavon (2019) concluded the importance of measuring the capacity of learners' oral production and the urgent need to conduct a real situation of teaching practices determining the interrelationship between intelligibility and oral fluency.

Much debate assumed the impact of oral feedback on modifying students' performance during an application of the spoken training strategies. The ideal and well-trodden tasks have to be built on a clear, well- organized and appropriate feedback to cover students' needs. The assessment of teaching progress is determined by the degree of how teachers reflect on students' performance through choosing a powerful designed integrative feedback to correct mispronunciation and inadequate choice of words, Solikhah (2016) assured that oral corrective feedback improve students' speaking competence, though the immediate correction of students' errors when they are speaking. Premarathne (2018) indicated the impact of a teacher's immediate feedback as a reaction of a student's utterance that constitutes a purposeful intention also, he asserted that oral corrective feedback had a positive effect on controlled speech and helped in producing an accurate format discourse level with continuous practice.

Similarly, Ningkrum (2020) analyzed oral corrective feedback used by the teachers to correct the students' error on 
their speaking performance. The study indicated that the teachers corrected the students' speaking errors, mostly in grammatical structure and pronunciation and recast and elicitation were the most frequented corrective feedback type used by English Teachers. Hence, the present study selected recast and elicitation feedback as an instrument that harmonized oral fluency and drama approach.

Drama approach and oral feedback may compensate the students' lack of intelligibility during practice spoken language, it used to examine the problems, situations, and tackle these problems through using artistic methods for teaching drama courses in the light of continuous oral corrective feedback. Both of them help teachers and students to reflect using actions to create an imagery of the dramatic plays and gives opportunities for students to express their thoughts, ideas, emotions to practice language, communicate effectively and edit their performance when they are performing different situations.

\section{ConteXt of The Problem}

On checking level seven students' oral fluency and intelligibility in a drama course (Shakespeare course) through applying a diagnostic test. The results showed that most students had low scores and lacked clarity and oral fluency. So, the researcher carried on an oral interview consisted of a checklist of twelve open -end questions to identify the problems and difficulties that faced student during learning and teaching Shakespeare course. The results of the interview proved that $88 \%$ of the level seven students faced problems during practicing oral skills even more than that, they need more practice and activities to improve their oral fluency. Soundscape, thought tracking and oral corrective feedback adopted by the teacher may compensate for information processing weaknesses students suffer from through emphasizing strengths and therefore, help them to speak more clearly and improve their oral skills.

\section{STATEMENT OF THE PROBLEM}

Most students in the English department lack the oral fluency and clarity required for English majors. This paper investigated the effect of drama approach (soundscape and thought tracking) and oral feedback on improving oral fluency and intelligibility of the English majors at Shaqra' university, Kingdom of Saudi Arabia.

\section{QUESTIONS OF THE PAPER}

1-To what extent does regular method affect students' intelligibility and oral fluency?

2-To what extent do soundscape and thought tracking strategies affect students' intelligibility and oral fluency?

3-To what extent does oral corrective feedback affect students' intelligibility and oral fluency?

\section{HYPOTHESES OF THE PAPER}

1- There was a significant difference between the average scores of the study groups at the .05 level due to conventional method in the pre-test of oral fluency and intelligibility.

2- There was a significant difference between the average scores of the study groups at the .05 level due to soundscape thought tracking strategies in the posttest of oral fluency and intelligibility.

3- There was a significant difference between the average scores of the study groups at the .05 level due to oral corrective feedback in the posttest of oral fluency and intelligibility.

\section{THE SigNIFICANCE OF THE PAPER}

This research solves the main problems faced by the students on the seventh level of the English department in drama course, improves the students' intelligibility and enhances oral fluency. It can also help teachers and students learn more about the different techniques of drama methods, which can effectively teach a Shakespeare course and improve oral fluency and language intelligibility.

\section{THEORETICAL BACKGROUND}

\section{A. Drama Approach}

The dramatic approach is defined as the way teachers participate in the entire classroom in the entire scene to create a dramatic world to explore and solve the problems face students in the communication process (Rosler, 2010). The present paper defined drama approach as the techniques used by both teachers and students to help students to be intelligible and speak more fluently in response to a drama course (Shakespeare's play "Hamlet" )to explore and tackle the problems that facing them during practicing oral skills.

\section{B. Oral Corrective Feedback}

Ölmezer-Öztürk\& Öztürk (2016) defined verbal corrective feedback as a technique used by teachers to modify the output in attractive ways. The present study defined as teacher's styles of correcting students' oral errors using recasts and elicitation to attract students' attention to correct errors and change their performance. 


\section{Intelligibility}

Choppens-Hofman \&Terband (2017) defined it as a person's ability to speak clearly, the speaker can understand and communicate with the speaker. The present study defined intelligibility as the ability of English major students to produce a very clear, and an accurate spontaneous speech to improve their oral language skills to comprehend dram course and perform the plays in natural speech.

\section{Oral Fluency}

Oral fluency is defined as how students read related texts smoothly, quickly and clearly (Kocaarsan, 2017). This paper defined oral fluency as the ability of students to speak clearly in a Shakespeare course (Hamelet), create suitable situations fluently, and produce natural speech.

\section{E. Related-studies}

Studies have pointed out that students lack oral proficiency and encounter many problems in oral development. Researchers have to study more research to improve students' ability to communicate fluently and easily (Greenfader \&et al, 2015; Nzanana, 2016; Wen, 2015). Alharbi(2015) indicated that students had problems in oral proficiency and Saudi students had low proficiency in English communication skills, Alharbi asserted that the system of education in the kingdom of Saudi Arabia had to reinforce the use of creative and contemporaneous approaches to improve oral skills of the students.

The traditional methods of teaching language skills have proven to be not effective and sufficient, therefore teachers have to search for different ways and vary their instructions to meet the students' need. One of the most effective and creative strategies are drama-based activities that can help learners to improve their abilities at different levels and at different ages. Many studies have compared traditional methods with dramatic methods. Galante \& Tomson (2016) investigated a study adopting the dramatic approach and its effect on oral fluency. The participants of the study were twenty- four students from English Brazilian learners. The researchers followed the experimental design following a drama instruction and comparing it to the traditional method. The Results of the pre-post tests indicated that dramabased techniques could be effective in improving English oral fluency more than the traditional EFL instruction.

Some studies have compared the effectiveness of drama-based activities as a learning strategy in the development of an oral English ability. Fauzan (2014) investigated a study aiming at exploring the effect of the improvisation technique on improving students' oral capacity of English majors at Widyagama Mahakam university, the study adapted the rubric of the oral proficiency assessment rubric. The results of the study proved that improvisation improved the speaking ability of the learners, and they have more positive attitudes towards oral abilities.

Man \& et al. (2019) indicated that students' had a serious problem in oral fluency in intermediate schools, thus they conducted a study to explore the effect of drama-based strategy on improving oral fluency. The study used interviews for fifteen weeks during the intervention, focusing on oral assessment, and classroom observation, adopting Cambridge English oral assessment based on vocabulary, grammar, pronunciation, discourse management and task completion. Results of the study showed there was an improvement in students' oral proficiency, and they achieved advanced levels especially in discourse management.

Lin and Francis (2014) examined the relationship between language intelligibility and oral fluency. The study measured the speech quality according to intelligibility and compared it to acoustic measures of fluency. The results of the study proved the high connection between language fluency and intelligibility are interacting in a very complex way.

Pishkar \& Dabaghi (2017) examined the role of modern English drama's texts on improving students' oral fluency and accuracy. Researchers distinguish between fluent learners, non-fluent learners, and imprecise learners. The results indicated that drama approach improved students' oral fluency and modern English drama's texts covered the gap between course-book dialogues and natural usage, and can help students to practice language in real-life situations.

The impact of oral corrective feedback in improving spoken language was investigated by Alsolami (2019) exploring the essential role of oral corrective feedback on the language oral skills, indicating that corrective feedback was used as a support strategy to improve learning process and provide a platform through which teachers can interact with their students. Additionally, Chehr, Farrokhi \& Zohrabi (2018) examined the effects of different corrective feedback on Iranian EFL learners' spoken accuracy and fluency. Results revealed that all groups were different in both the extensive recast and delayed explicit metalinguistic groups' spoken accuracy in favor of recast. Another research was investigated by Farrokhi \& et al. (2017) to examine the effects of different types of oral feedback on Iranian English students' fluency and accuracy. The researcher used the intensive recast and explicit metalingustic feedback. Results showed that corrective feedback had no significant effects on the EFL pre-intermediate level learners' spoken accuracy. Solikha (2016) studied the impact of oral feedback on oral skills. The participants were 30 students from the English department, Bantara University. The study used recasts, explicit, implicit and clarification requests. Results revealed that students' performance influenced positively by corrective feedback. Unsal (2020) investigated error correction in EFL classes based on students' perspectives. The samples of the study were 65 students at Kafkas University. The results indicated that $90 \%$ of the learners would like to be corrected when they had errors during the process of speaking English. 


\section{A. Design of the Study}

This paper applied the quasi-experimental design with quantitative and qualitative data collection. Participants' of paper were divided into an experimental group which exposed to two strategies of drama approach and three types of oral corrective feedback. The control group was taught using conventional method.

\section{B. The Paper's Participants}

Two groups of thirty students from the level seven in the English department, Shaqra University, Kingdom of Saudi Arabia. The sample of the paper was purposely selected, they were divided into an experimental group and a control group each one contained fifteen, they were assigned to answer the pre-post oral tests and participated in the piloting of the interview. Participants are all women, aged between 20-22. Their oral fluency is between medium and low levels. Both the control and the experimental had the same characteristics. Each student had the same serial number in all the stages of the experiment. The control group received the conventional method, whereas the experimental exposed to the intervention. The researcher was the teacher of the course, her age was 40 with 18 years of college teaching experience. The participants were provided with sufficient information about the experiment, the tools used, their responsibilities, the steps in the experiment, the method of evaluation, and their right to withdraw.

\section{The Instruments of the Paper}

1- An interview.

2- The pre- post oral tests to compare the effect of soundscape and thought tracking strategies on intelligibility and oral fluency.

3- A Rubric of the Scoring Scale.

4- An Observation checklist based on the analysis of drama strategies and oral corrective feedback.

\section{Teaching Procedures}

In the first semester of the 2018/2019 academic year, the duration of this experiment is sixteen weeks. The study examined the effects of two strategies of drama approach soundscape and thought tracking with two types of corrective feedback recasts and elicitation on intelligibility and oral fluency through teaching Hamlet for level seven as in the course description of Shakespeare course. The research is divided into three teaching stages. Firstly, the researcher taught both groups using the conventional method for seven weeks, then measured the intelligibility and oral fluency of the two groups using a rubric scoring score based on intelligibility and fluency, which included intonation, voice quality, speech rate, numbers of pauses, vocabulary and structure (Table2). Secondly, the control group used the conventional methods to complete the course, while the experimental group received two drama strategies through three oral feedback corrections. (Table1) below showed the procedures of the experiment. Observation was applied through taking notes and records, the researcher wrote the students' response to each type. Lastly, the researcher applied the post- oral tests for the two groups to compare the results. A committee composed of two teachers and researcher from the English department shared in the evaluation process of the pre-posttest.

TABLE (1)

PROCEDURES OF THE EXPERIMENT IN THE FOLLOWING TABLE :

\begin{tabular}{|c|c|c|c|c|}
\hline Groups & Tests & $\begin{array}{l}\text { strategies of } \\
\text { drama }\end{array}$ & Oral corrective Feedback & Tests \\
\hline \multirow[t]{2}{*}{ Experimental group1 } & \multirow{3}{*}{$\begin{array}{l}\text { Pre oral - } \\
\text { test }\end{array}$} & Soundscape & $\begin{array}{l}\text { Recasts/Elicitation } \\
\text { /Clarification request }\end{array}$ & \multirow{3}{*}{$\begin{array}{l}\text { Post oral } \\
\text { test }\end{array}$} \\
\hline & & Thought tracking & $\begin{array}{l}\text { Recasts/Elicitation/ } \\
\text { Clarification request }\end{array}$ & \\
\hline Controlgroup2 & & Conventional & Conventional & \\
\hline
\end{tabular}

\section{Drama approach strategies:}

\section{Thought tracking:}

Students played the roles in Hamlet's play through continuous and sustained roles using clear oral language. They focused on pitch, tone, volume when speaking. Students were oriented, directed and followed up by the teacher.

\section{Soundscape:}

According to Hamlet's acts, students used various tones, rhythms and words to perform scenes. Students need to understand the situation first, and then they think about speech speed, sentence stress, intonation and tone to match them with the situation. Teacher warmed-up and modeled soundscape through choosing certain situations from the play to brainstorm speech.

\section{Oral corrective feedback strategies:}

Recasts: When a student made a wrong speech to indirectly help him/her express the correct form, the teacher will repeat the speech several times to help them produce the correct forms.

S: his feel and most unnatural mother......

T: Revenge his foul and most unnatural murther.....

It is not (Refenge) but (Revenge), It is not(feel) but (foul) It is not(mother) but (murther).

Elicitation: Teacher uses fill in the blanks, questions and pauses give opportunities to complete utterance after 
repeating the correct forms when the student produces erroneous speech to help him/her directly to produce the correct forms.

S: O all you loost of heaven! earth !

T: What (host)...... O earth ........

Clarification request: Teacher uses request phrases such as (could you..-Do you think...-Sorry - Excuse me- I wonder if ...-What.. - Pardon me.. etc) to show that he misunderstand when the student produces erroneous utterance.

S: So my anseption prevent you discovery ....

T: Excuse me! What? Repeat again

S: So shall my anticipation prevent your discovery.....

TABLE (2)

RUBRIC OF THE SCORING SCALE OF INTELLIGIBILITY AND FLUENCY

\begin{tabular}{|c|c|c|}
\hline Norms & Scores & Criteria \\
\hline \multirow[t]{3}{*}{ Intelligibility } & $15-12$ & $\begin{array}{l}\text { Excellent to very good: 1-voice quality is clear with slight distortion of pronunciation but not affect } \\
\text { intelligibility. 2-Intonation is placed correctly closer to native speakers. 3-sentence-level stress is appropriate } \\
\text { and understandable, but with few stress mistakes but not affect intelligibility. }\end{array}$ \\
\hline & $11-8$ & $\begin{array}{l}\text { Good to average: 1-The voice quality is clear, the pronunciation is moderate, and the voice is always clear and } \\
\text { recognizable. 2-Intonation is sometimes inappropriate. 3-sentence -level stress is understandable, but with some } \\
\text { stress mistakes, which sometimes affect intelligibility. }\end{array}$ \\
\hline & $7-0$ & $\begin{array}{l}\text { Fair to very poor: 1-voice quality is mostly unclear, and severe pronunciation distortion makes the voice difficult } \\
\text { to understand. 2-Intonation is always inadequate, hard and causes misunderstanding. 3-sentence -level stress } \\
\text { needs the listener to focus more to follow the speaker, and make speech hard to understand. }\end{array}$ \\
\hline \multirow[t]{3}{*}{ Fluency } & $15-12$ & $\begin{array}{l}\text { 1-Excellent to very good: 1-Speech rate is fast, regular and smooth, without repetition or hesitation, but smooth } \\
\text { ideas require more time. } \\
\text { 2-Number of pauses are very limited and short pauses occurred, but not more than two. 3-Vocabulary is } \\
\text { appropriate and use vocabulary effectively with minor errors which not affect meaning. 4- Grammar: speaker } \\
\text { uses a high control of structure basics with minor errors, which not affect sentences structures. }\end{array}$ \\
\hline & $11-8$ & $\begin{array}{l}\text { Good to average: 1-Speech rate is accepted, but uneven, with many repetitions, and indecision. It takes a long } \\
\text { time for the flow of ideas. 2-Number of pauses: long pauses occurred more than two times. 3-Vocabulary is } \\
\text { accepted with some lexical inadequacies that affecting the meaning. 4- Grammar: the student makes frequent } \\
\text { errors in tenses with minor errors in words' order. }\end{array}$ \\
\hline & $7-0$ & $\begin{array}{l}\text { Fair to very poor: } 1 \text { - Speech rate: the speech is slow and jagged, repeated many times, with many hesitations and } \\
\text { inappropriate thoughts. 2-Number of pauses increased and prevented connecting ideas. 3-Vocabulary is } \\
\text { inappropriate, short and affect meaning. 4- Grammar: speaker has poor control of structure basics with severe } \\
\text { errors which affect sentences structures and makes speech incomprehensible. }\end{array}$ \\
\hline
\end{tabular}

\section{E. Homogeneity between Groups in the Oral Proficiency Tests}

The results in the following table (3) and (4) indicated that in the pretest, no significant differences were found between the two groups. Therefore, it is assumed that the two groups are statistically equivalent, and any difference in the post-test results can be attributed to the treatment.

TABLE (3)

RESults of Homogeneity of VARIANCES LEVENE STATISTIC TEST For THE CONTROL AND EXPERIMENT GROUP BEFORE THE EXPERIMENT (INTELLIGIBILITY) PRETEST ( $\mathrm{DF}=28)$.

\begin{tabular}{l|l|c|c|c|c|} 
& & Levene Statistic & df1 & df2 & Sig. \\
\hline \multirow{2}{*}{ Intelligibility } & Based on Mean & .654 & 1 & 28 & .426 \\
\cline { 2 - 7 } & Based on Median & .289 & 1 & 28 & .595 \\
\hline
\end{tabular}

TABLE (4)

Results of Homogeneity of VARIANCES LEVEnE STATISTIC TEST FOR THE CONTROL AND EXPERIMENT GROUP BEFORE THE EXPERIMENT (FLUENCY) PRETEST (DF = 28).

\begin{tabular}{|c|c|c|c|c|c|}
\hline & & Levene Statistic & df1 & df2 & Sig. \\
\hline \multirow[t]{2}{*}{ Fluency } & Based on Mean & 2.551 & 1 & 28 & .121 \\
\hline & Based on Median & 1.474 & 1 & 28 & .235 \\
\hline
\end{tabular}

\section{F. Validity and Reliability of Intelligibility and Fluency Tests}

The reliability showed that the Cronbach's Alpha of intelligibility test was .763 and fluency was.776, which indicated that the tests were reliable.

\section{PResentation of Results and Discussions}

The paper displayed a set of descriptive statistics and performs a normal distribution test for all variables in the study, thereby selecting an appropriate statistical test for the study variable set in the following table. The following table (5) summarized the descriptive statistics of all variables. 
TABLE (5)

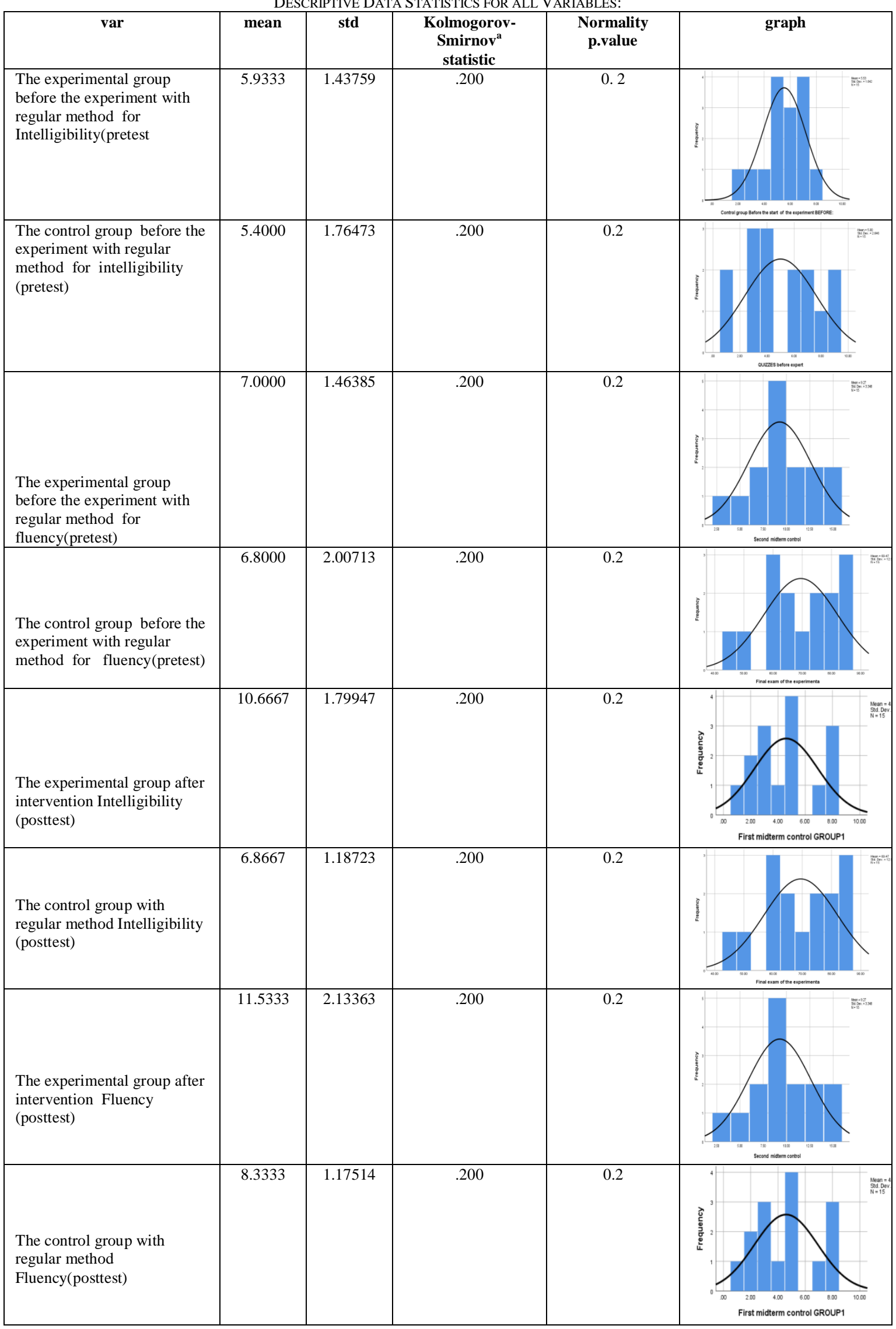

Table (5) above showed the average value, standard deviation, Kolmogrov-Smirnov statistics and normality distribution of the pretest. Normality tests indicated that its p-value and normal distribution graph shown that all 
variables are normally distributed, so parameter statistics are used.

The paper displayed a set of descriptive and inferential statistics were used to test this hypothesis: to what extent does the regular strategy affect students' intelligibility and oral fluency?

TABLE (6)

RESUlts OF THE PARAMETRIC PAIRED SAMPLES ORAL TEST BEFORE THE START OF THE EXPERIMENT WiTH THE REGULAR METHOD.

\begin{tabular}{|c|c|c|c|c|c|c|c|c|c|}
\hline & & \multicolumn{5}{|c|}{ Paired Differences } & \multirow[b]{3}{*}{$\mathrm{t}$} & \multirow[b]{3}{*}{ df } & \multirow{3}{*}{$\begin{array}{l}\text { Sig. (2- } \\
\text { tailed) }\end{array}$} \\
\hline & & \multirow[b]{2}{*}{ Mean } & \multirow{2}{*}{$\begin{array}{c}\text { Std. } \\
\text { Deviati } \\
\text { on }\end{array}$} & \multirow{2}{*}{$\begin{array}{c}\text { Std. Error } \\
\text { Mean }\end{array}$} & \multicolumn{2}{|c|}{$\begin{array}{c}95 \% \text { Confidence Interval of } \\
\text { the Difference }\end{array}$} & & & \\
\hline & & & & & Lower & Upper & & & \\
\hline Pair 1 & $\begin{array}{l}\text { The experimental group with regular } \\
\text { method for Intelligibility - The } \\
\text { control group with regular method for } \\
\text { Intelligibility }\end{array}$ & .53333 & 1.99523 & .51517 & -.57159 & 1.63826 & 1.035 & 14 & .318 \\
\hline Pair 2 & $\begin{array}{l}\text { The experimental with regular method } \\
\text { for fluency - The control group with } \\
\text { regular method for fluency }\end{array}$ & .20000 & 2.07709 & .53630 & -.95025 & 1.35025 & .373 & 14 & .715 \\
\hline
\end{tabular}

The results shown in table (6) above ,there was no significant differences were found between the two groups in the pre-test, due to the conventional methods, $(\mathrm{Sig}=.318, .715)$.

The paper displayed a set of descriptive and inferential statistics were used to test this hypothesis to what extent do soundscape and thought tracking strategies affect students' intelligibility and oral fluency?

TABLE (7):

RESUlTS OF THE PARAMETRIC PAIRED SAMPLES ORAL TEST AFTER THE START OF THE EXPERIMENT WITH INTERVENTION.

\begin{tabular}{|c|c|c|c|c|c|c|c|c|c|}
\hline & & \multicolumn{5}{|c|}{ Paired Differences } & \multirow[b]{3}{*}{$\mathrm{t}$} & \multirow[b]{3}{*}{$\mathrm{df}$} & \multirow[b]{3}{*}{ Sig. (2-tailed) } \\
\hline & & \multirow[b]{2}{*}{ Mean } & \multirow{2}{*}{$\begin{array}{c}\text { Std. } \\
\text { Deviation }\end{array}$} & \multirow{2}{*}{$\begin{array}{l}\text { Std. Error } \\
\text { Mean }\end{array}$} & \multicolumn{2}{|c|}{$\begin{array}{l}95 \% \text { Confidence Interval of the } \\
\text { Difference }\end{array}$} & & & \\
\hline & & & & & Lower & Upper & & & \\
\hline Pair 1 & $\begin{array}{l}\text { The experimental group } \\
\text { after intervention } \\
\text { Intelligibility - control } \\
\text { group with regular method } \\
\text { Intelligibility }\end{array}$ & 3.80000 & 1.99523 & .51517 & 5.07662 & 2.52338 & 6.384 & 14 & .000 \\
\hline Pair 2 & $\begin{array}{l}\text { The experimental group } \\
\text { after intervention Fluency - } \\
\text { control group with regular } \\
\text { method Fluency }\end{array}$ & 3.20000 & 2.07709 & .53630 & 4.57572 & 1.82428 & 4.989 & 14 & .000 \\
\hline
\end{tabular}

The results in table (7) above indicated that there was a significant difference between the two groups, which was beneficial to the students in the experimental group, which can be attributed to the intervention $(\operatorname{Sig}=.000)$.

Observation was used to test this hypothesis: To what extent does oral corrective feedback affect students' intelligibility and oral fluency?

TABLE (8)

OBSERVATION RESULTS OF ORAL CORRECTIVE FEEDBACK

\begin{tabular}{|c|c|c|c|c|c|c|c|c|}
\hline \multirow[t]{2}{*}{ No } & \multirow{2}{*}{$\begin{array}{c}\text { Oral corrective feed } \\
\text { back }\end{array}$} & \multicolumn{5}{|c|}{ Frequency of Use in Every Act in Hamlet } & \multirow{2}{*}{$\begin{array}{l}\text { Total of } \\
\text { Frequency }\end{array}$} & \multirow{2}{*}{$\begin{array}{l}\text { Percentage } \\
\text { s }\end{array}$} \\
\hline & & Act1 & Act2 & Act3 & Act 4 & Act5 & & \\
\hline 1 & Recast & 15 & 22 & 10 & 21 & 6 & 74 & $23.5 \%$ \\
\hline 2 & Elicitation & 20 & 32 & 15 & 16 & 9 & 92 & $29.3 \%$ \\
\hline 3 & Clarification Request & 30 & 42 & 42 & 21 & 13 & 148 & $47.2 \%$ \\
\hline \multicolumn{7}{|c|}{ Total } & 314 & $100 \%$ \\
\hline
\end{tabular}

The results in Table (8) above, indicated that all the three types were used by the teacher during teaching Shakespeare course (Hamlet). The percentages showed that clarification request had the highest percent, $47.2 \%$ then elicitation had $29.3 \%$ and the lowest one was recast $23.5 \%$.

TABLE (9)

OBSERVATION RESULTS OF DRAMA APPROACH STRATEGIES

\begin{tabular}{|c|c|c|c|c|c|c|c|c|}
\hline \multirow{2}{*}{ No } & \multirow{2}{*}{$\begin{array}{c}\text { Drama approach } \\
\text { strategies }\end{array}$} & \multicolumn{6}{|c|}{ Frequency of Use in Every Act in Hamlet } & \multirow{2}{*}{$\begin{array}{c}\text { Total of } \\
\text { Percentages }\end{array}$} \\
\cline { 3 - 9 } & Act1 & Ac2 & Act3 & Act4 & Act5 & & 17 & $68 \%$ \\
\hline 1 & Thought tracking & 3 & 4 & 4 & 4 & 2 & 0 & $32 \%$ \\
\hline 2 & Soundscape & 1 & 2 & 3 & 2 & 0 & 25 & $100 \%$ \\
\hline
\end{tabular}

The results in Table (9) above, indicated that the two types were used by the students during teaching Shakespeare course (Hamlet). The percentages showed that thought tracking $=68 \%$ was higher than soundscape $=(32 \%)$. 


\section{FINDINGS}

According to the findings of the paper, the results were discussed according to its steps:

1- In the first step, the researcher evaluated the students' intelligibility and fluency after using the conventional method in both groups the mean of intelligibility in the control $=(5.400)$ whereas in the experimental $=(5.933)$. The average fluency of the control group $=(6.800)$, and the average fluency of the experimental group $=(7.000)$, which indicates that the levels of the two groups are roughly the same, and there is no difference between the two groups.

2- In the second step, the researchers used the observation techniques to evaluate students' response to oral corrective feedback and drama approach strategies, results showed that teachers used clarification request mostly because students preferred it to recast and elicitation. The superiority of clarification request over the others may be related to several reasons, such as, characteristics of Saudi girls; they are very sensitive, shy and very polite, so that, clarification request may be the best choice, also the experience of the students, individual differences may attribute in their preference. In this paper, student preferred thought tracking rather than soundscapes for the following reasons: the teacher noticed that students enjoyed more in performing characters more thinking of producing accurate utterance, and teacher found that practicing of thought tracking is easier than soundscape.

3- The final step of the paper displayed the results of the post-test to compare the results, the average of intelligibility in the control $=(6.86)$ whereas in the experimental $=(10.66)$ also, It is also the average of fluency in controls $=(8.33)$ whereas in the experimental $=(11.53)$ results showed a difference between two groups in the posttest in favor of experimental group due to the treatment.

\section{IMPLICATION}

There evidences that the identification and recognition of different types of dramatic methods and oral feedback affect the degree of progress in oral language skills. Both strategies help to reduce problems when practicing oral skills, so drama methods and oral feedback can be used in the teaching of other courses in the English department, such as listening and speaking courses, and reading comprehension courses. By surveying the results of the students in literature courses in the English department at Sharqra' proved that students' need more creative strategies to improve their performance in these courses, hence the present paper strategies can attribute in improving and supporting them to raise their levels in literary courses.

\section{RECOMMENDATIONS}

Based on this paper, the following recommendations are made:

1- Language intelligibility and fluency should be given more attention in our EFL classes. More time and efforts should be spent to enhance them.

2- Supportive and sustained oral corrective feedback should be offered throughout drama courses to help students identify their weaknesses and encourage them to increase their involvement and motivation.

3- Further research is needed sorely to explore the issue of how to help the students at several and different levels to develop and enhance oral fluency and intelligibility.

4- Additional studies should pursue the investigation of the relationships between students' performance, oral skill measures and instructions.

5- Further research is needed to examine the effect of drama approach and oral corrective on language accuracy.

\section{REFERENCES}

[1] AlHarbi, H.A. (2015). Improving students' English speaking proficiency in Saudi public schools. International Journal Instruction 8(1):105-116. DOI: 10.12973/iji.2015.818a.

[2] Alsolami, R. (2019). Effect of oral corrective feedback on language skills. Theory and Practice in Language Studies, 9, 6, 672677.http://dx.doi.org/10.17507/tpls.0906.09.

[3] Blake, H. L \& et al. (2019) Intelligibility Enhancement Assessment and Intervention: a single-case experimental design with two multilingual university student. Journal of Clinical Linguistics \&Phontics, 34(1-2), 22.doi/abs/10.1080/02699206.2019.1608470.

[4] Becker, M. R. (2013). Intelligibility of English as a lingua Franca: Perception of speakers with different L1s by speakers of Brazilian Portuguese. Unpublished doctoral dissertation, UFPR, Brazil.

[5] Chehr Azad, M. H., Farrokhi, F., \& Zohrabi, M. (2018). Corrective Feedback, Spoken Accuracy and Fluency, and the Trade-off Hypothesis. International Journal of Instruction, 11(2), 465- 482. https://doi.org/10.12973/iji.2018.11232a.

[6] Farrokhi,F.\& et al .(2017).The Effect of the corrective feedback on Iranian EFL learners' speaking accuracy and breakdown Fluency. Journal of Language Horizons, Alzahra University.1 (2), 107-129. DOI: 10.22051/lghor.2018.16786.1064.

[7] Fauzan, U. (2014). The use of improvisations technique to improve the speaking ability of EFL students. Dinamika Ilmu, 14(2), 264-287.

[8] Francis, A. L.( 2014). The relationship between fluency, intelligibility, and acceptability of non-native spoken English. Acoustical Society of America journal 135(4):22-27. doi/abs/10.1121/1.4877285.

[9] Galante, A. \&Tomson, R.(2016) . The effectiveness of drama as an instructional approach for the development of second 
language oral fluency, comprehensibility, and accentedness. TESOL Quarterly 51(1), 115-142. doi/abs/10.1002/tesq.290.

[10] Greenfader, C. M., Brouillette, L. \& Farkas, G. (2015). Effect of a performing arts program on the oral language skills of young English learners. Reading Research Quarterly, 50(2), 185-203. doi:10.1002/rrq.90.

[11] Guzel, M. C. (2017). Developing oral proficiency and motivation through script-based and improvisational drama. California State University, San Bernardino.

[12] Kocaarslan, M. (2017). A research about oral reading fluency of first grad students: text type and gender factor .Journal of Education and practice 8, 23, 1735-2222.

[13] Lin, A.L. (2014). The relationship between fluency, intelligibility, and acceptability of non-native spoken English . Journal of Acoustical Society of America, 135, 4, 22-27. https://doi.org/10.3389/fpsyg.2014.00651.

[14] Mallen, A.M. \& Pavon.V. (2019). The Improvement of intelligibility in the oral production of standard English: A study about the production of vowel quality in stressed and unstressed syllables. English Language Teaching 12(4):115. DOI:10.5539/elt.v12n4p115.

[15] Man, C. F et al. (2019). Exploring the use of drama-based activities as a learning tool in English oral proficiency development among students from non-Malay medium nation schools: A preliminary study. International Journal of Academic Research in Business and Social Sciences, 9(6), 1202-1215. http://dx.doi.org/10.6007/IJARBSS/v9-i6/6082.

[16] Ningkrum, C.A. (2020). Analysis of oral corrective feedback on students' speaking performance in EFL classes. A Case Study of Eleventh Graders of SMA Negeri .English department. Negeri University.

[17] Nzanana, J. B. (2016). Language learning motivation and oral proficiency learners of English as a foreign language: The case of university students in Rwanda. Michigan State University.

[18] Ölmezer-Öztürk, E., \& Öztürk, G. (2016). Types and timing of oral corrective feedback in EFL classrooms: Voices from students. NovitasROYAL (Research on Youth and Language), 10(2), 113-133.

[19] Pishkar.K \& Dabaghi1.A.(2017). Modern English drama and the students' fluency and accuracy of speaking. Journal of English Language Teaching, 10, 8, 69-77. http://doi.org/10.5539/elt.v10n8p69.

[20] Premarathne, K.(2018). The effect of explicit corrective feedback on phonological intelligibility. International Journal of Humanities and Social Science 23(9):11-19. DOI:10.9790/0837-2309061119.

[21] Rosler, B. (2010). Process drama in one social studies classroom. Journal of social studies, 99,265-272. Doi/abs/10.3200/TSSS.99.6.265-272.

[22] Solikha, I.(2016). Oral corrective feedback in speaking class of English department. LINGUA: Journal of Language, Literature and Teaching, 13(1), 87-102.

[23] Thomson. R. (2015). The Handbook of English Pronunciation: Fluency, Wiley-Blackwell, pp.209-226. DOI: 10.1002/9781118346952.ch12.

[24] Unsal, S.H. (2020). Oral corrective feedback preferences of university students in English communication classes. International Journal of Research in Education and Science (IJRES), 6(1), 172-178.

[25] Wen, I.C. (2015). The effectiveness of learning through drama in Chinese as a second language. Miami University.

[26] Weinberger, S. (2013). Speech accent archive. George Mason University. https://accent.gmu.edu.

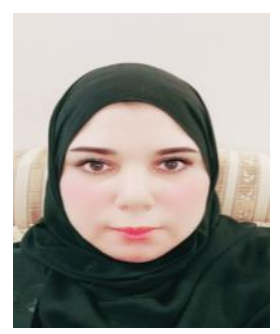

Samah Ahmed Mohammed Elborolosy, B.A in English language, Faculty of Arts \& Education, Ain Shames University, Egypt. M.A in Teaching English as a foreign language, Faculty of Humanities, Al- Azhar University, Egypt. PhD in TEFL, Institute of Research and Educational Studies, Egypt. Lecturer at Faculty of Humanities, Al-Azhar University, Egypt. Lecturer at English Department, Faculty of Science \& Humanities, Shaqraa University Kingdom of Saudi Arabia .With 17 years experience in university teaching. Recently, she published four researches 2 in 2019 and 2 in 2020 and this is the fifth one. 